

\section{POSSIBLE INTRA-SPECIFIC KILLING BY A GREAT GRAY OWL}

by ROBERT M. FISHER*

On January 23, 1974, at 12:00 p.m., I observed a possible case of intraspecific "predation" by a Great Gray Owl. The location was 15 feet off Highway 93 (Lat. 117 26' Long. $\left.52^{\circ} 27^{\prime}\right)$ at 5000 feet above sea level in Jasper National Park, Alberta. The ambient air temperature was about $-3^{\circ} \mathrm{C}\left(26^{\circ} \mathrm{F}\right)$, with a southwest wind gusting to $20 \mathrm{mph}$.

The observation of a Great Gray Owl standing on top of a dead Great Gray Owl was made from a bus containing 20 students. Upon stopping the bus, the feeding bird flew off. Examination of the site did not reveal any signs of a significant struggle. The thin body of the dead owl was still warm. No blood was found, nor were broken bones or external hemorrhages present. A small area of skin had been opened on its breast, and there was a hole approximately 1.5 inches in diameter in the ear area. Feathers were scattered in small quantities downwind from the site.

This observation implies one of at least two things: 1) The owl was feeding on carrion or 2) The owl preyed upon an individual of its own kind.

The Great Gray Owl preys almost entirely on mice and voles. 1235 ; 8 : In some cases birds have been found to constitute small portions of the Great Gray Owls diet: Common Crow, 'Redpoll, " and Hazel Hen." The taking of birds by Great Gray Owls must be assumed to be uncommon; of 4,026 prey items examined in their study of pellets, Mikkola and Sulkava found $1.1 \%$ avian remains, including finches,

* 8030 - 132nd Ave.,

Edmonton. Alberta.

T5C $2 \mathrm{~B} 4$ adult and young game bir (Tetraonidae), two jays (Garrulus gla dularis) and a Tengmalmis $\mathrm{O}$ (Aegolius funereus). ${ }^{\star}$ In Canad however, Brunton and Pittaway $h$ not observed the Great Gray Owl feed on birds."

One could assume that the dead o may have been hit by an automobi but park wardens informed us that road had been closed to public tra up to this date because of danger fr avalanches. We were the fi travellers on it for some time, ot than the wardens. This informati and the lack of external hemorrha suggest that the Great Gray Owl tacked and killed an individual of own kind, possibly an individ diseased or starved to a point wh the live bird responded to its abnor behavior.

My thanks to R. W. Fyfe and A. Oeming for their helpful remarks reviewing the manuscript.

'BENT, A. C. 1938. Life histories of $\mathrm{N}$ American birds of prey. Part 2. U.S. Natl. Bull. 167. Dover edition, 1961.

"BRUNTON, D. F., and R. PITTAWAY 1971. Observentioms of the Great Gray Ow/ on ter remge. Can. Field-Nat. 85: 315-322.

"CRAIGHEAD, J. J., and F. C. CRAIGHE Jr. 1956. Hawks, ow/s and wildlife. D edition, 1969. $443 \mathrm{pp}$.

'FISHER, A. K. 1893. The hawks and owls o. United States. U.S. Dept. Agri.

"GODFREY, W. E. 1967. Some winter aspee the Great Gray Ow\%. Can. Field-Natt. 81: 99-

"HOOGLUND, N. H., and E. LANSGREN. The Great Gray Owl and its prey in Swe Viltrevy 5: 363-416.

'LAW, C. 1960. The Great Gray Owl of wordlands. Blue Jay 16: 14-16.

${ }^{*}$ MIKKOLA, H., and S. SULKAVA. 1970. of Great Gray Ow/s in Fonno-Scandia. B Birds 63: 23-27.

"NERO, R. W. 1969. The status of the Great ": Owl in Manitoba, with special reference th the 1968-1969 influx. Blue Jaly 27: 191-209. 